\title{
Cutaneous Melanoma pT1 TNM Finding v6
}

National Cancer Institute

\section{Source}

National Cancer Institute. Cutaneous Melanoma pT 1 TNM Finding v6. NCI Thesaurus. Code C48842.

Cutaneous melanoma $1.0 \mathrm{~mm}$ or less in thickness, with or without ulceration. (from AJCC 6th Ed.) 